\title{
Najkrótszy przewodnik po moim ojcu. Z Martą Herling rozmawia Magdalena Śniedziewska ${ }^{1}$
}

Czy pamięć o Gustawie Herlingu-Grudzińskim jest nadal żywa $w$ Waszej rodzinie?

To wspomnienie bardzo żywe, ale wiąże się także z poczuciem ogromnej pustki. Ojciec był niezwykłą postacią, którą - razem z moim bratem Benedettem - nieustannie staramy się upamiętnić, również dzieląc się wspomnieniami w gronie przyjaciół oraz podejmując różne kulturalne inicjatywy. I, oczywiście, zamierzamy je kontynuować. Chciałabym jednak zaznaczyć, że czynią to także wnuki. Patrizio, syn Benedetta, czytał ostatnio z ogromnym emocjonalnym zaangażowaniem Inny Świat, żeby zrozumieć (dla samego siebie) znaczenie pamięci o dziadku, którego de facto dobrze nie poznał i którego nie pamięta, ponieważ obaj wnukowie byli bardzo mali, gdy Gustaw Herling-Grudziński zmarł. To ważny przykład i ogromna radość. Wraz z Benedettem, po śmierci naszej matki Lidii w 2015 roku, jesteśmy bardzo zaangażowani w promowanie dzieł

1 Wywiad był elementem projektu Odojewski i Herling-Grudziński. Doświadczenie dwóch pokoleń, finansowanego przez Muzeum Historii Polski w Warszawie w ramach programu „Patriotyzm Jutra”. 
ojca we Włoszech. Działania te umożliwiły wydanie pokaźnego wyboru dzieł Herlinga-Grudzińskiego w serii Meridiani (o czym szerzej jeszcze powiem). Współpracujemy z instytucjami, które zainicjowały i zorganizowały festiwal Herlinga-Grudzińskiego w Neapolu. Podsumowując, można więc powiedzieć, że pamięć o ojcu jest wyraźnie obecna w naszej rodzinie i chcielibyśmy, by jego postać stała się wzorem dla nas wszystkich.

W Polsce 2019 rok byt Rokiem Herlinga-Grudzińskiego, w wielu ośrodkach akademickich i kulturalnych obchodzono setna rocznice jego urodzin. A jak we Wtoszech, przede wszystkim zaś w Neapolu, upamiętniono Herlinga-Grudzińskiego?

We Włoszech odbyły się dwa niezwykle ważne wydarzenia: pierwsze miało charakter edytorski, drugim natomiast był festiwal w Neapolu. Promocja wydania dzieł spełniła marzenie nasze i naszej matki, by utwory Herlinga-Grudzińskiego, które miały we Włoszech liczne edycje, z którymi związane były różne perypetie, doczekały się wydania w prestiżowej serii Meridiani, ukazującej się nakładem wydawnictwa Mondadori. Chciałabym podkreślić, że latach 90. oficyna Feltrinelli z powodzeniem publikowała utwory ojca: Diario scritto di notte w 1992 roku, Un mondo a parte w 1994 roku, Ritratto veneziano w 1995 roku i Don Ildebrando w 1999 roku. Było to możliwe dzięki zaangażowaniu Francesca Cataluccia. W 2017 roku w serii Oscar Moderni ukazał się Inny Świat, który został w ten sposób upowszechniony i poddany pod ponowną dyskusję. Książka ta znalazła się w centrum zainteresowania kultury światowej, nie tylko włoskiej. Wydawnictwo Mondadori na nowo odkryło Herlinga-Grudzińskiego. Renata Colorni (redaktorka serii Meridiani, w ramach której publikuje się najważniejsze dzieła literatury powszechnej) doceniła niezwykłą wielkość pisarza, bowiem to Mondadori zaproponowało publikację w serii Meridiani. Praca nad wydaniem była ograniczona czasowo bardzo restrykcyjnie przez datę jubileuszową: rok 2019. W Mondadori chcieli, by tom ukazał się w rocznicę urodzin. Licząca ok. 1600 stron edycja pod redakcją Krystyny Jaworskiej opatrzona jest przedmową Włodzimierza Boleckiego Konteksty europejskie twórczości Gustawa Herlinga oraz 
tekstem Goffreda Fofiego Herling w Neapolu. Świadectwo, ja opracowałam Chronologię. Herling-Grudziński powraca we Włoszech do czołówki pisarzy europejskich. Pojawily się liczne recenzje jego książek w dziennikach i czasopismach. Z kolei festiwal Neapol Herlinga zorganizowało kilka instytucji, m.in. Instytut Polski w Rzymie, dwa neapolitańskie uniwersytety: „L'Orientale” i Suor Orsola Benincasa oraz Włoski Instytut Studiów Historycznych. Festiwal trwał od 24 do 26 października 2019 roku. To święto - bardzo bogate trzy dni przygotowało miasto na uczczenie pisarza. Uroczystość otwarcia odbywała się w Sali Baronów w zamku Maschio Angioino, a więc w miejscu uwielbianym przez Herlinga. Towarzyszyły jej niezwykłe emocje, obecni byli m.in. prezydent Neapolu, ambasadorka Polski we Włoszech Anna Maria Anders, rektorka uniwersytetu „L'Orientale” - to dowód ogromnego uznania. Wydarzenia te miały istotne znaczenie i były wielkim hołdem oraz potwierdzeniem, że Herling-Grudziński jest częścią tego miasta. Uczestniczyło w nich wiele osób, także liczni studenci i młodzież. Mój ojciec jest częścią Neapolu, a dzięki festiwalowi i edycji swych dzieł w serii Meridiani znalazł się na samym szczycie. Więcej osiągnąć już nie mógł.

W Polsce Herling-Grudziński jest pisarzem wspóttworzacym literacki kanon. Wszyscy w szkole średniej czytaja "Inny Świat” jako lekture obowiazkowa. Czy we Wtoszech za sprawa wydania "Innego Świata” z 2017 roku i tego z roku 2019, które ukazato się w serii Meridiani, dzieło Herlinga-Grudzińskiego może wejść do kanonu lektur?

Jeśli chodzi o kwestię Innego Świata jako lektury obowiązkowej zobaczymy... Ale mogę już teraz powiedzieć, że za sprawą serii Meridiani została podjęta inicjatywa w dwóch liceach w Rzymie, które postanowily wprowadzić u siebie Inny Świat jako lekturę. Później odbyło się spotkanie w ambasadzie polskiej, w którym uczestniczyli uczniowie tych szkól, byłam też ja oraz przedstawiciele wydawnictwa Mondadori. Toczyła się dyskusja. To była niezwykle znacząca inicjatywa. Mondadori promuje tę książkę w szkołach. Założenie jest takie, by - obok Czy to jest człowiek Primo Leviego - czytało się Inny Świat. Muszę powiedzieć, że dzięki edycjom w seriach Oscar Moderni oraz Meridiani, a także 
neapolitańskiemu festiwalowi, który miał duży oddźwięk, poznałam wielu nauczycieli zainteresowanych lekturą Innego Świata. I to moim zdaniem - jest ważna zmiana, która stopniowo dokonuje się na naszych oczach.

We Wtoszech, a przede wszystkim w Neapolu, jest potrzebne miejsce, które upamiętniałoby Herlinga-Grudzińskiego. Czy możliwe jest stworzenie muzeum pisarza, które mieściłoby się w jego domu przy via Crispi?

To kwestia bardzo delikatna. Jestem całkowicie przekonana o tym, że powinna istnieć rozpoznawalna przestrzeń Herlinga-Grudzińskiego jako pisarza, i naturalnie po festiwalowych wydarzeniach, o których rozmawiałyśmy, to jest nasze marzenie na przyszłość.

Czy jest możliwe, by badacze i studenci pracowali nad rękopisami Herlinga-Grudzińskiego znajdującymi się w archiwum?

Archiwum w 2004 roku zdeponowano w Palazzo Filomarino należącym do Fundacji Benedetta Crocego (taka była wola naszej matki, a także wskazanie ojca). Następnie zostało uporządkowane i skatalogowane $\mathrm{w}$ ramach projektu realizowanego przez Bibliotekę Narodową w Warszawie, finansowanego w całości przez Ministerstwo Kultury. Umowę podpisywał dyrektor Biblioteki Narodowej Tomasz Makowski, zaś z ramienia Fundacji Benedetta Crocego moja matka Lidia i ja. Prace trwały kilka lat i już się zakończyły, dzięki zaangażowaniu archiwistów z Biblioteki Narodowej i grupy fotografów. Teraz archiwum jest opracowywane i inwentaryzowane w wersji cyfrowej. Pod redakcją Joanny Borysiak powstał katalog (wydany w 2019 roku przez Bibliotekę Narodową), który będzie dostępny on-line na stronach Biblioteki Narodowej i Fundacji Benedetta Crocego. Dokumenty zostały zeskanowane i po dopełnieniu procedury upoważnienia (za zgodą, m.in. moją) zarówno polscy, jak i włoscy badacze mogą zapoznać się z zawartością archiwum $\mathrm{w}$ formie cyfrowej. Oryginalne dokumenty trzeba chronić, stąd możliwość pracy jedynie z ich wersją zdigitalizowaną. 
Wiemy, że stosunek Herlinga-Grudzińskiego do Neapolu się zmieniat. Pod koniec życia Twój ojciec pokochat to miasto, ale na samym początku nie lubit go. Mogtabyśs spróbować wyjaśnić, czym jest „Neapol Herlinga"?

„Neapol Herlinga” to chiaroscuro, światło i cień, albo lepiej scurochiaro: najpierw cień, potem światło. Podobnie w jego wizji malarstwa przenikają się światło i cień, co możemy spostrzec w dziennikowych zapisach. Jeśli ktoś zaczyna lekturę od Dziennika 1957-1958 - dotychczas nieznanego, który opublikowałam w 2018 roku razem $\mathrm{z}$ Włodzimierzem Boleckim w Wydawnictwie Literackim - to ma do czynienia z pierwszym dokumentem pisanym tuż po tym, jak ojciec na stałe zamieszkał w Neapolu. I tam dostrzegalny jest właśnie scurochiaro. Neapol to miasto, które odkrywa, którym Herling-Grudziński jest zafascynowany, a jednocześnie miejsce, w którym doświadcza głębokiej samotności (mam tu na myśli izolację). Te dwa doświadczenia: fascynacji i samotności w podobnych proporcjach istnieją także później. Chodzi mi o obcość wobec miasta, w relacjach z miastem - bo tak było. Jednak istotna okazała się również fascynacja - Neapol stał się przestrzenią do odkrycia i ojciec odkrywał miejsca, historie, legendy, które następnie okazywały się źródłem inspiracji do jego opowiadań. Myślę, że wraz z upływem czasu, przede wszystkim w latach 90., pogodził się z tym miastem. Sam był stopniowo odkrywany i przyjmowany w nowych środowiskach intelektualnych i kulturalnych. Na przykład w „Il Mattino” ukazywały się jego artykuły, wywiady z nim. Sądzę, że wraz z publikacjami w „Il Mattino” dokonywało się pojednanie Herlinga-Grudzińskiego z miastem. W Dzienniku pisanym noca znajdują się niezwykłe fragmenty, w których ojciec pisze o tym, że nie może dłużej bronić się przed pokochaniem Neapolu. I podkreśla, że - tak jak dla Jusepe de Ribery - Neapol jest dla niego miastem, które wybrał na miejsce swojej śmierci. To ważne, bo Neapol jest miastem, w którym odnalazł swoją przystań, w którym później czuł się jak w domu, przede wszystkim w ostatnich latach swojego życia. Tak więc „Neapol Herlinga”, co próbowaliśmy pokazać w trakcie trzydniowego neapolitańskiego 
festiwalu, ma różne oblicza. I jest także punktem dojścia życiowej wędrówki pisarza.

Wspominataś o Riberze. Czy także dla Ciebie to ważny artysta? WNeapolu można oglądać jego dzieła, np. w Certosa di San Martino znajduje się „Komunia apostotów”, jest też piękny obraz w pinakotece Pio Monte della Misericordia. Ogladasz dzieła Ribery oczami Twojego ojca czy masz jakąś wtasną wizję tego artysty?

Moja wizja jest silnie uwarunkowana tym, co ojciec pisał o Riberze (Herling-Grudzińśki był jednym z tych, którzy Riberę odkryli) i jak opowiadał o jego życiu, w jaki sposób objaśniał tę sztukę.

Chciałabym teraz nieco zmienić temat i porozmawiać o utworach Herlinga-Grudzińśkiego. W Polsce to pisarz znany przede wszystkim jako autor „Innego Świata”. Także we Włoszech ten tekst stat się ważny. W Polsce jednak opowiadania Herlinga-Grudzińskiego nie sa tak rozpoznawalne, jak „Inny Świat”. Czy, Twoim zdaniem, istnieje różnica między Herlingiem-Grudzińskim jako autorem „Innego Świata” a Herlingiem-Grudzińskim jako autorem dziennika i opowiadań, czy raczej jest to pisarz catkowicie spójny?

Inny Świat to zarówno niezwykłe świadectwo, jak i książka złożona z ukrytych w niej portretów oraz opowieści. Z kolei opowiadania otwierają nowy etap w życiu i twórczości pisarza - to niewątpliwe. Dzięki nim pojawiają się odmienne obrazy, wartości. Inny Świat jest dziełem, za sprawą którego Herling-Grudziński zostaje niejako „uświęcony” w przestrzeni literatury (sam wspomina, że jako pisarz narodził się w gułagu). Późniejsza droga pisarska, ta dziennikowa, otwiera nowe horyzonty, staje się świadectwem epoki - Herling-Grudziński jest narratorem, moralistą. Co istotne, jeśli powrócimy do włoskiego kontekstu, dostrzeżemy, że opowiadania mają swoją stendhalowską nić - kronik włoskich i neapolitańskich; to jest pisarstwo, które się niejako objawiło za sprawą losu, przeznaczenia, kiedy Herling-Grudziński trafil do Italii (jako wygnaniec we Włoszech). Wielu badaczy zwraca uwagę na ten moment, w którym twórczość ojca zaczyna „karmić się” włoską przestrzenią, czerpie 
inspiracje z Włoch, i wówczas on sam staje się ważny także jako autor opowiadań - i tak jest do dziś we Włoszech.

Kiedy czyta się wtoskie recenzje, dostrzega się znaczenie kontekstu włoskiego, który jest w nich silnie eksponowany. Na przykład odbiór opowiadania „Pietà dell'Isola” w Polsce byt catkowicie odmienny od jego włoskiej recepcji. W Polskich pracach nie spotyka się tak wyraźnych prób ukonkretnienia, nazwania wyspy. We Włoszech już na wstępie podkreśla się, że Isola to Capri. Czy ta wyspa byta dla Herlinga-Grudzińskiego miejscem szczególnym?

Tak, bardzo.

Dzięki zabytkom i pejzażowi? Czy jest może coś jeszcze, co zbliżyło Herlinga-Grudzińskiego do Capri?

Według mnie była to jakaś głęboka duchowa więź. Pejzaż, zabytki, o czym wspominasz, również, ale było jeszcze coś, coś głęboko duchowego. Być może Capri stała się symbolem wyspy wygnania. Musimy pamiętać, że Capri jest także wyspą Księcia niezłomnego i Tyberiusza. To przestrzeń nasycona historią, jest tam Kartuzja, a więc miejsce kultu religijnego, magiczne. Przede wszystkim jednak wyspa staje się symbolem wygnania, czegoś zamkniętego - to osobny świat. W pięknej rozmowie z Boleckim o opowiadaniu Pietà dell'Isola Herling-Grudziński mówi, że w pewnym sensie to świat zamknięty, inny. A jego świat to „inny świat”. Więc to wyspa wygnania. Z Neapolu ogląda się Capri, która jest niejako po drugiej stronie, staje się miejscem duchowego doświadczenia. W Księciu niezłomnym Herling-Grudziński umieszcza tam postaci wzorowane na Crocem i Silonem. Ci dwaj bohaterowie mieli odmienne wizje wygnania. Moim zdaniem ważne jest więc także duchowe znaczenie tej wyspy.

Wspominataś o chronologii życia i twórczości Herlinga-Grudzińskiego, jaka przygotowywałaś do edycji, opublikowanej w ramach serii Meridiani. Czy we Włoszech to jest pierwszy tak obszerny tekst poświęcony biografii ojca? W Polsce ukazywaty się liczne prace o charakterze biograficznym. Jak to wygladato we Wtoszech? 
We Włoszech pierwszy. Są takie krótkie portrety, wprowadzające np. artykuł Cataluccia, będący wstępem do edycji Un mondo a parte z 2017 roku. Mój tekst nosi tytuł Chronologia, ponieważ tak została pomyślana seria Meridiani. Chronologia, czyli przebieg życia z podziałem na lata. Powołuję się tam na dokumenty dotąd nieznane, fragmenty listów, świadectw. Cały tekst liczy ok. 70 stron. Po raz pierwszy zrekonstruowana została w nim w sposób bardzo szczegółowy biografia Herlinga-Grudzińskiego. I - co wynika z założeń serii Meridiani - w Chronologii kładzie się nacisk na autoprezentację samego autora. Przywołuję zatem fragmenty dzienników (i tego prywatnego, z lat 1957-1958, i Dziennika pisanego noca), listów, świadectw w taki sposób, jakby tworzyły biografię opowiadaną przez ojca. Istotne były dla mnie także liczne prace o charakterze biograficznym, które ukazywały się w Polsce. Myślę przede wszystkim o szkicach Boleckiego i Zdzisława Kudelskiego te fragmenty literaturoznawczych książek o ojcu są mi szczególnie bliskie.

Kontekst autobiograficzny w twórczości Herlinga-Grudzińskiego jest bardzo istotny. Gdy nauczyłaś się języka polskiego, traktowałaś dzieła swojego ojca jako źródto wiedzy o nim?

Tak, pięknie to ujęłaś. To był jedyny kontakt z moim ojcem jako pisarzem. Przede wszystkim taki miałam cel: mówić po polsku, żeby go zrozumieć, żeby lepiej zrozumieć własnego ojca, żeby móc wejść z nim w dialog. Działo się tak głównie dlatego, że był on człowiekiem bardzo tajemniczym i niezwykle fascynującym w tym swoim gabinecie, w osobnym świecie, który rozumieliśmy, i którego nie rozumieliśmy zarazem. Ponadto ojciec miał wiele sekretów, tajemnic. Czułam więc, że jednym z kluczy do odkrycia niektórych $\mathrm{z}$ nich będzie poznanie rodzimego języka ojca. I co bardzo ważne, a co zdarzyło się po jego odejściu, moim pragnieniem, niezwykle silnym, było zrekonstruowanie autobiografii ojca za pośrednictwem jego pism. Dlatego niektóre z nich opublikowałam po włosku. Przetłumaczyłam Najkrótszy przewodnik po sobie samym (Breve racconto di me stesso) i wydałam tom Pielgrzym wolności (Il pellegrino della libertà), w którym zebrałam zapiski ojca połączone ze sobą za 
sprawą wątków autobiograficznych, począwszy od Godziny cieni, która jest arcydziełem.

Czytając utwory swojego ojca napotkataś jakieś aluzje do Twojej biografii?

Nie, właściwie nie. Myślę, że obecne są inne postaci: w niektórych tekstach osoba mojej matki, być może wspominany jest Benedetto. A może Tobie udało się coś zlokalizować? Ale nie wydaje mi się...

Nie.

No właśnie.

$W$ Polsce w trakcie obchodów rocznicowych postać Lidii Croce, Twojej matki, nie byta tak dobrze wyeksponowana, jak to miało miejsce podczas neapolitańskiego festiwalu, kiedy m.in. prezentowano dwie ważne publikacje: katalog zbiorów prywatnej biblioteki Herlinga-Grudzińskiego przywieziony przez Piotra Kłoczowskiego i inwentarz archiwum Herlinga-Grudzińskiego opracowany i wydany przez Bibliotekę Narodowa; obie ksiażki dedykowane sa „in memoriam Lidia Croce”. W moim przekonaniu to bardzo ważne, by także w Polsce docenione zostało znaczenie Twojej matki w życiu i twórczości Herlinga-Grudzińskiego. Bez Lidii nie byłoby Herlinga-Grudzińskiego jako pisarza, jako polacco napoletano.

To prawda. Można nawet powiedzieć, że Lidia stała się dla niego ratunkiem. W wielu aspektach tak było. Myślę, że w sposób bardzo dobitny wyraził to Wojciech Karpiński w swoim szkicu G.H.G.: droga i dom. To piękny hołd złożony Lidii. Bez Lidii Herling-Grudziński nie byłby tym pisarzem, którym się stał. I z pewnością ich historia miała taki właśnie sens. Od pierwszego zetknięcia w Sorrento do spotkania w Monachium, gdzie ponownie się odnaleźli w 1955 roku. Myślę, że mama głęboko go rozumiała i przywróciła go życiu w najbardziej dramatycznych dla niego momentach. Stworzyła mu także miejsca (np. ten gabinet), które okazały się nieodzowne dla niego jako pisarza, bo później nim właśnie się 
stał. I chcę jeszcze wspomnieć o tym wszystkim, co zrobiła po śmierci ojca. Ta działalność była dla niej bez wątpienia najważniejszym przedsięwzięciem, którego się podjęła, dzięki ogromnemu doświadczeniu archiwistycznemu i edytorskiemu. Śledziła krytyczne wydanie Dziet Zebranych w Wydawnictwie Literackim, pragnęła uporządkować archiwum we współpracy z dyrektorem Biblioteki Narodowej Tomaszem Makowskim. Masz rację, katalog archiwum został poświęcony jej pamięci, ponieważ cały ten projekt w taki sposób realizowany zawdzięczamy jej wysiłkom. Podobnie ma się rzecz z opublikowanym przez Kłoczowskiego inwentarzem prywatnej biblioteki Herlinga-Grudzińskiego w jego studio w Villa Ruffo. Także wydanie Dziennika 1957-1958 naturalnie dedykowane jest mamie, ponieważ ona wiedziała, że ten dziennik, którego tata nie zdecydował się wydać, ale który przechowywał, bez jej zgody nie zostałby opublikowany. Jednak ona bardzo chciała, by ten tekst się ukazał. Jedno z ostatnich pytań, które zadawała, dotyczyło daty publikacji prywatnego dziennika ojca. To także stało się jednym z jej pragnień. Miała wielkie serce i była zawsze tuż obok mojego ojca, dlatego pamięć o niej powinna przetrwać.

Z pewnością nie da się zrozumieć Herlinga-Grudzińskiego bez znajomości „Innego Świata”. Które z opowiadań jest, Twoim zdaniem, istotne, by opisać kondycję Herlinga-Grudzińskiego jako emigranta w Neapolu?

Myślę, że są dwa takie opowiadania. Pierwsze, za sprawą którego możemy odczuć los wygnańca i jego samotność, to Wieża. Nawet jeśli akcja tego utworu nie rozgrywa się w Neapolu, to opowiada o pewnym uniwersalnym doświadczeniu, o samotności i wygnaniu w sposób absolutnie niezwykły. Myślę, że jako drugie należy wskazać jedno z ostatnich opowiadań Herlinga-Grudzińskiego: Podzwonne dla dzwonnika, niesamowicie wizjonerskie, do którego warto powracać. To utwór nasycony wątkami autobiograficznymi, podejmujący problem losu i dramatyczną refleksję na temat tego, co wydarzyło się w minionym stuleciu. Muszę powiedzieć, że to opowiadanie bardzo sugestywne, które łączy opis niektórych ukochanych przez HerlingaGrudzińskiego miejsc w Neapolu, jak Santa Chiara, z niemiecką historią z czasów kryształowej nocy. Dlatego ogromną przyjemnością 
było przypomnienie tego opowiadania w trakcie neapolitańskiego festiwalu. Poświęciliśmy temu utworowi jeden wieczór, niezwykły, właśnie w Santa Chiara, gdzie Podzwonne dla dzwonnika było czytane przez jednego z najwybitniejszych aktorów włoskich - Toniego Servillo. Wszyscy byli pod ogromnym wrażeniem, przeżywając to opowiadanie, słowa mojego ojca, w tym miejscu.

Czy kiedy czytataś „Łuk Sprawiedliwości”, odczuwałaś potrzebę odwiedzenia Chiesa di Sant'Eligio Maggiore, by zobaczyć opisywane tam miejsce, lub chciałaś ujrzeć most z utworu o takim tytule? Czy lektura opowiadań ojca rodzi chęć ponownego odwiedzenia opisywanych miejsc?

Mam wrażenie, że czuję to nie tylko ja. To potrzeba wszystkich czytelników, ponieważ opowiadania bardzo żywo związane są z opisywanymi w nich miejscami i dlatego rodzi się konieczność ich zobaczenia. Są przedstawiane w sposób niezwykły. Sądzę, że w przyszłości, kiedy ukończony zostanie w Wydawnictwie Literackim wielki projekt edycji krytycznej Dziet Zebranych, kierowany przez Boleckiego, wspólpracującego z wieloma badaczami, wśród których jesteś także Ty, musimy zacząć myśleć o edycjach-antologiach fragmentów z Dziennika pisanego noca i opowiadań, które mogłyby się stać przewodnikiem po Neapolu i południu Włoch. Byłby to rodzaj „Kronik neapolitańskich”, by odwołać się do Kronik wtoskich Stendhala. Za pośrednictwem tych opowiadań można wyznaczyć trasy wędrówek po „Neapolu Herlinga”.

Moglibyśmy zatytułować ten tom „Praktyczny przewodnik po Neapolu Herlinga", czyniac aluzję się do tytutu jego pierwszego wtoskojęzycznego artykutu „Giuda essenziale della Polonia”, który ukazat się w 1944 roku na tamach pisma "Aretusa”.

Albo Kroniki neapolitańskie. Istnieje już edycja rosyjska.

Tak?

Tak, to bardzo osobliwe. Ale oczywiście trzeba to wydać także w Polsce. W Petersburgu dzieło ukazało się w pięknej edycji wydaw- 
nictwa Limbach w opracowaniu Mariusza Wilka. Dziennikarz przemierzał Neapol śladami Herlinga-Grudzińskiego i ostatecznie nie wyjechał z miasta, lecz zamieszkał tam na kilka lat, zgłębiając problem „Neapolu Herlinga”. Ta książka to antologia fragmentów Dziennika pisanego noca i opowiadań, których tematyczną nicią przewodnią jest Neapol. Ten tom wyszedł po rosyjsku właśnie jako Kroniki neapolitańskie. To piękny tytuł, ponieważ odsyła do Stendhala. Pewnego dnia wydamy to także po polsku. Według mnie w Polsce musimy poszukać także innych dróg, by przybliżyć czytelnikom twórczość mojego ojca.

Edycja krytyczna to coś wyjątkowego, ale musimy w Polsce znaleźć jeszcze inny sposób promowania twórczości Herlinga-Grudzińskiego przede wszystkim opowiadań - świeżego pomystu wydawniczego, by upowszechnić jego dzieła.

Wielki projekt edycji krytycznej jest bardzo ważny. Podkreślam to zawsze, ponieważ zebrane zostały wszystkie teksty i ustalone ich wersje. Wydanie Dziet zebranych zawiera ponadto analizę wariantów utworów. To przedsięwzięcie, biorąc pod uwagę inne wydania krytyczne, np. włoskie, które są mi znane, realizowane jest z niewiarygodną sprawnością. W momencie domknięcia tej ogromnej edycji Wydawnictwo Literackie będzie musiało pomyśleć o nowych projektach wydawniczych, które dzieło Herlinga-Grudzińskiego ukażą na innych poziomach, by jego twórczość została rozpowszechniona w szerszym gronie czytelników.

Wiem, że przettumaczyłaś kilka utworów swojego ojca. Co myślisz o sobie jako jego ttumaczce?

Mogę powiedzieć, że to jest szczególnie fascynujące, ponieważ jego język jest naprawdę niezwykły. Próba ukazania go w innym języku, takim jak włoski, i wzniesienia na ten sam poziom, oddania piękna jego stylu, to było dla mnie cudowne doświadczenie - i bardzo znaczące. Była to także przyjemność przekładania i interpretowania, ale w pewnym stopniu również wyzwanie - tłumaczenie jego pisarstwa. Naprawdę fascynująca przygoda. 
Znasz zarówno polski, jak i wtoski. Czy, Twoim zdaniem, czytanie Herlinga-Grudzińskiego po polsku i po wtosku to zupetnie inne doświadczenie?

Nieuniknione jest oczywiście to, że wersja włoska stanowi tłumaczenie. To niewątpliwie coś innego. Sądzę, że trzeba poczynić refleksję, którą - jak pamiętam - dzielił się także mój ojciec: że w używanej przez niego polszczyźnie odczuwalny jest nieznaczny wpływ języka włoskiego, jego składni i stylistyki. Jeśli chodzi o przekłady - jest Inny Świat, który z angielskiego przełożyła moja mama, słuchaliśmy aktorskiej interpretacji tego opowiadania - to było oczywiście tłumaczenie, ale ta włoska wersja jest naprawdę osobliwa. Jeśli mówi się o języku włoskim Herlinga-Grudzińskiego, trzeba wspomnieć Scritti italiani, które zebrałaś i opracowałaś. To ważne źródło, ponieważ składa się z tekstów, które ojciec sam napisał po włosku. Mają bardzo szczególny styl, co należałoby zbadać.

Dzięki „Pismom wtoskim” wiemy, jak dobrze Herling-Grudziński władał językiem wtoskim. Jak sądzisz, dlaczego Twój ojciec nigdy nie zdecydowat się na to, by samodzielnie przettumaczyć swoje utwory?

On sam? Nie... Dla niego to były dwie odrębne rzeczy. Polski odczuwany „bezpośrednio - cienka i unerwiona skóra na nagich dłoniach" (jak mówił w trakcie swojego wystąpienia w Poznaniu w 1991 roku) - to był jego język. Nie mógł zatem stać się tłumaczem samego siebie na włoski, ponieważ to polski był jego językiem. Nie mam co do tego wątpliwości.

W Waszym domu mówito się po włosku, to byt język życia codziennego. Czy włoski Herlinga-Grudzińskiego byt włoskim neapolitańczyka, czy jednak styszeliście, że to język Polaka?

Włoski Polaka. Odczuwało się niezwykle fascynujące drobne różnice składniowe. Kiedy słucha się jego licznych wywiadów udzielanych po włosku, odczuwa się inność, jakieś obce nuty, ślady. Neapolitańskiej melodii zdania nie potrafił odtworzyć. 
Wedtug niektórych badaczy język polski Herlinga-Grudzińskiego, zwłaszcza w latach 9o., zmienit się pod wptywem języka wtoskiego. Czy ojciec zgadzat się z tymi opiniami?

Nie potrafię tego precyzyjnie usytuować w czasie, ale sądzę, że zdawał sobie sprawę z tego, iż włoskie komponenty są obecne w jego języku i pisarstwie, że zostały one wchłonięte. Nie wiem, jaki był jego pogląd na ten temat, ale mam wrażenie, że mógł odczuwać także pewien rodzaj zadowolenia. Myślę, że określenie „Herling polacco napoletano", którego używano w stosunku do niego, uważał za zabawne. Śmiał się z niego, ale w pewnym sensie tak właśnie się czuł - jak pisarz polsko-włoski. Herling-Grudziński to naprawdę wielki, fascynujący pisarz europejski.

\section{Przet. Magdalena Śniedziewska}

Magdalena Śniedziewska

The Shortest Guide to My Father. Magdalena Śniedziewska's Interview with Marta Herling ${ }^{2}$

The interview is devoted to Gustaw Herling-Grudziński. The writer's daughter, Marta, talks about her father, particularly focusing on the Italian contexts of his biography and writings. Also discussed is the problem of the writer's attitude towards the Italian language and the reception of his works in Italy. Another important topic is Naples as a fascinating source of writing inspirations and, at the same time, the city where Herling-Grudziński happened to live and die.

Keywords: Gustaw Herling-Grudziński; Naples; reception of Herling-Grudziński's work in Italy.

Marta Herling-Grudziński - urodziła się w Neapolu w 1957 roku, uzyskała stopień doktora, jest autorką studiów i tłumaczeń poświęconych polskiej historiografii i kulturze XIX i Xx wieku. Od 1988 roku pełni funkcję sekretarz 
generalnej Włoskiego Instytutu Studiów Historycznych (Istituto Italiano per gli Studi Storici) założonego przez Benedetta Crocego. Opiekuje się Archiwum Gustawa Herlinga-Grudzińskiego znajdującym się w Fundacji „Biblioteka Benedetta Crocego”, w której zarządzie również zasiada. Koordynuje proces wydawania dzieł ojca w Polsce, we Włoszech oraz w innych krajach. Brała udział w konferencjach i publikowała liczne artykuły o HerlinguGrudzińskim w polskich i włoskich czasopismach oraz tomach zbiorowych. W 2007 roku została odznaczona przez Ministra Kultury RP Złotym Medalem Zasłużony Kulturze - Gloria Artis.

Magdalena Śniedziewska - polonistka i italianistka, adiunkt w Zakładzie Teorii Literatury w Instytucie Filologii Polskiej Uniwersytetu Wrocławskiego. W latach 2015-2018 adiunkt w Pracowni Poetyki Historycznej IBL PAN w ramach programu FUGA (NCN). Autorka książek: Wierność rzeczywistości. Zbigniew Herbert o postawie wobec świata i problemach jego reprezentacji (2013), Siedemnastowieczne malarstwo holenderskie w literaturze polskiej po 1918 roku (2014), „Osobiste sprawy i tematy”. Gustaw Herling-Grudziński wobec dwudziestowiecznej literatury włoskiej (2019), „Nuta autobiograficzna”. O twórczości Gustawa Herlinga-Grudzińskiego (2019). Zajmuje się związkami literatury i malarstwa, recepcją literatury włoskiej w Polsce oraz motywami ptasimi w literaturze. Adres e-mail: magdalena.sniedziewska@uwr.edu.pl. 
